\title{
Interaction Patterns of Teachers and Students in the Learning Scaffolding Process: Reviews in the Al Quran Surah 'Abasa verses 1 - 10
}

\author{
Imam Kusmaryono ${ }^{1}$, M. Abdul Basir ${ }^{2}$ \\ Universitas Islam Sultan Agung, Jl. Kaligawe Raya KM 4, Semarang 50112, Indonesia ${ }^{1,2}$ \\ \{kusmaryono@unissula.ac.id 1, abdulbasir@unissula.ac.id ${ }^{2}$ \}
}

\begin{abstract}
The interaction of teachers and students in the teaching and learning process is a very determining factor in achieving learning objectives. If the teacher and student interactions are not harmonious, it can hinder the achievement of learning objectives. The focus of the study of this paper is the interaction pattern of teachers and students in the learning scaffolding process in the review of Al Quran Surah 'Abasa verses 1 - 10. The study method used is the thematic method and the study method. Data were analyzed through content analysis techniques objectively and systematically. The results of the study of the Al-Qur'an surah 'Abasa verses 1 - 10 regarding the interaction patterns of teachers and students in the learning process show (1) there is an interactive between teacher and student (one-to-one scaffolding), and (2) interaction between students and students (peer-scaffoldding).
\end{abstract}

Keywords: Review, Interaction, Scaffolding, Surah Abasa.

\section{Introduction}

The discussion about educators and the educational process in Al-Qur'an is one form of scientific effort that really needs to be done. Especially if it is related to the needs of the world of education today. The stories in the Koran can be used as learning material in the educational process. The hope is that this story can have implications for changes in teacher and student behavior [1],[2]. Allah SWT explicitly affirms in His words, the surah Yunus verse 57 which means as follows, "Hi people, actually wisdom has come from your Lord and medicine for diseases in the chest as well as guidance and mercy for those who believe“"

In education, optimal learning outcomes are influenced by learning components. For example, how to organize the material, the methods applied, the media used, and so on. In addition to these components, there are other factors that influence student learning success, namely the relationship between teachers and students. The relationship between teachers and students in the teaching and learning process is a very determining factor [3]. However, the learning materials presented are good and the methods used are perfect, but if the teacherstudent interaction is not harmonious, it can hinder the achievement of learning objectives [4]. To establish this good relationship, a teacher must understand that in a heterogeneous class there are unique and diverse student characteristics with various individual differences, both from biological, intellectual, and psychological aspects. 
Interactions with educational value are interactions that consciously set goals to change a person's behavior and actions [3]. So the terms teacher on the one hand and student on the other emerged. Both are in interaction with educational value with different positions, duties, and responsibilities, but still, work together in achieving learning goals (education). The teacher is responsible for leading students towards maturity by providing a number of knowledge and guiding them. Meanwhile, students are actively trying to achieve educational goals with the help and guidance of teachers [5]. Teachers as learning facilitators function more as providing assistance or scaffolding support to their students in achieving learning objectives [6],[7]. In the process of achieving learning objectives, scaffolding is mainly given to students having difficulty solving learning problems. Therefore, the interaction between teachers and students or students and students must be optimized in the form of scaffolding support. Based on a review of some research literature and expert opinion [6],[8],[9],[10],[11],[12],[13] can be summarized that scaffolding in learning is defined as a didactic action in the form of measurable and limited assistance or encouragement for students provided by others (a student who have experience or more knowledge) in understanding the concept or context being studied so that students will independently be able to build knowledge and solve problems.

Scaffolding assistance in learning can include illustrations, hints, motivation, warnings, keywords, an outline of the problem to simpler steps towards how to solve the problem, giving examples, and other assistance which must all be clear and relevant to enable students to achieve. developmental level of independent learning [10],[14]. The Qur'an is believed to be a book of guidance and a source of value for Muslims. The Qur'an provides many explanations for how the educational process should be carried out. However, the concept of the Qur'an has not been implemented in a concrete manner to guide educational development, especially with regard to the concept of educators and the interaction of educators and students in the educational process. There is a need for an educator who can carry out their functions properly and as role models to carry out education based on the values of the Qur'an, so we need a concept that can synergize the two in a more integrated teaching (education) field. The purpose of writing this scientific article is to (1) analyze the pattern of teacher-student interaction that occurs in the learning scaffolding process in terms of the study of the AlQur'an letter Abasa verses 1 - 10, and (2) provide recommendations to teachers to always refer to the Al Quran. in solving various problems faced in learning.

\section{Research Method}

This literature review uses a systematic approach to critically analyze patterns of interaction between teachers and students in learning in terms of the Al-Qur'an surah Abasa verses 1 - 10. According to Dixon-Woods [15],[16], Systematic literature is defined as "a scientific process governed by a set of explicit and demanding rules oriented towards demonstrating completeness, immunity from bias, and transparency and accountability of techniques and execution". This is a process of collecting qualitative and quantitative data from relevant literature to compare and evaluate the ability of a particular phenomenon to solve problems [15]. The systematic review process is characterized by several criteria that are used to limit the scope of the review [16]. The search for literature studied in this study was obtained from valid sources, namely the Book of the Al-Qur'an Surah Abasa verses 1 - 10. Furthermore, these criteria are used as the standard for assessing the weight (evidence) in the research included in this review. Data analysis techniques through content analysis namely, 
techniques to draw conclusions through efforts to find the characteristics of the message and be carried out objectively and systematically.

\section{Result and Discussion}

\subsection{Interpretation of Al Quran surah 'Abasa verses 1-10}

As a guide for the discussion in this study, a snippet of the Al Quran surah 'Abasa verses $1-10$ is presented along with its translation.

Table 1. Translation of Al Quran Surah Abasa verses1 -10

\begin{tabular}{lc}
\hline \multicolumn{1}{c}{ Translation of Al Quran Surah Abasa } & Verses \\
\hline He (Muhammad) surrendered and turned away, & Verse 1 \\
Because someone blinded to him had come, & Verse 2 \\
$\begin{array}{l}\text { Do you know maybe he wants to clean himself (from sin), } \\
\text { Or he (wants) to get teaching, then that teaching benefits him, }\end{array}$ & Verse 3 \\
As for those who feel sufficient, & Verse 4 \\
Then you serve him, & Verse 6 \\
Even though there is nothing (reproach) for you if he does not & Verse 7 \\
clean himself (beliefs), & \\
And as for those who come to you hastily (to get teaching), & Verse 8 \\
While he was afraid of (Allah), & Verse 9 \\
Then you ignore it. & Verse 10 \\
\hline
\end{tabular}

Surah 'Abasa Verses 1 - 2: "He (Muhammad) turned sour and turned away because a blind man had come to him". It is reported that when He (Prophet Muhammad SAW) was busy explaining Islam to the figures of the polytheists (Quraish) of Mecca. Prophet Muhammad SAW hoped that his invitation could touch the hearts and minds of the musyirikin (Quraish) so that they were willing to embrace Islam. If the Quraish leaders converted to Islam, it would have a positive impact on the development of Islamic preaching. But that was when a blind man named Ibn Ummi Maktum came and did not know the activities of the Prophet Muhammad SAW, then Abdullah Ibn Ummi Maktum interrupted the talk of Prophet Muhammad SAW by begging him to teach him what Allah had taught to Prophet Muhammad SAW. According to history, the words of Ibn Ummi Maktum were said many times and caused displeasure in the heart of the Prophet Muhammad. However, the Prophet Muhammad SAW did not rebuke or scold Ibn Ummi Maktum, it was just that the Prophet Muhammad's expression appeared displeased, his face looked sour and he looked away. Then the Surah 'Abasa Verses 1 - 2 came down, to rebuke the Prophet Muhammad SAW for his attitude towards Ibn Ummi Maktum.

According to the scholars, what Ibn Ummi Maktum did was considered impolite if he knew that the Prophet Muhammad was busy with other people (guests) and he hoped for his Islam. However, Allah SWT still rebuked the Prophet (Muhammad) for his actions that had turned away from Ibn Ummi Maktum as incapable of Muslims. Ibn Ummi Maktum did not feel disappointed with the attitude that the Prophet Muhammad had made towards him. Allah SWT admonishes the attitude of Prophet Muhammad SAW so that everyone will know that a poor believer is better than a wealthy infidel, and shows that a believer is superior and better, even though he is a pauper than paying attention to wealthy people because want their faith, even though this action is one of benefit. 
The mention of the word (عَبَ) "Abasa" in the form of a third persona, then does not directly refer to the Prophet Muhammad SAW who was being reprimanded, indicating how subtle the reprimand was and how even Allah in educating the Prophet Muhammad SAW did not accuse him or explicitly blame him. Surah 'Abasa Verses 3 - 4: "Do you know maybe he wants to clean himself (from sin), or he (wants) to get teaching, then the teaching benefits him,". The above verse explains that what makes you know is that you will not know even if you try hard regarding someone's heart. It is possible that he (friend) who is blind wants to clean himself, namely to do good deeds and to strengthen his faith by listening to religious teachings even though his level of faith is not too solid or he wants to get teaching so that it is useful for him even though the teaching he receives is not too much.

The Prophet Muhammad's disregard for Ibn Ummi Maktum then received a warning from Allah in verses 3-4 in this surah. The meaning of verses 3-4 is, If the Prophet Muhammad SAW knew the purpose of Ibn Ummi Maktum who asked to teach Islam and hear the recitation of the Qur'anic verses, it would have been of greater benefit to him and better for him. Verses 3 - 4 explain about sharia education (worship) which is carried out with fellow humans (muamalah), namely by not thinking negatively about others before you really know what the intentions and goals of the people who come to you. Surah 'Abasa Verses 5-10: "As for those who feel that they are sufficient, then you serve him, whereas there is no (reproach) on you if he does not clean himself (believes), And as for those who come to you hastily (to get teaching), While he was afraid of (Allah), then you ignore him.

The above verse explains the attitude of the Prophet Muhammad SAW towards the idolatrous figures (Quraish) who are very much expected to be Muslim. As for people who feel they don't need the Prophet Muhammad because they have property, children, social position, and knowledge, even though these idolaters do not have the motivation to fear Allah SWT, you (Prophet Muhammad SAW) only serve him, not to the blind man served him by thoroughly explaining the teachings of Islam. Actually, the attitude of the Prophet Muhammad SAW towards the idolatrous figures (Quraish) was driven by his fear that the Prophet Muhammad SAW was judged to have not carried out his duties properly. So that this admonition was continued by stating: "You, Hi Great Prophet, did that, but there is no reproach on you if he, the polytheist princes, do not clean themselves, namely disbelieving even in the slightest level. And whoever comes to you hastily is attentive to get attention while he is afraid of Allah, then on the contrary, you are against him with an attitude of neglect.

Meanwhile, at that time, there was someone who was blind (Ibn Ummi Maktum) who needed him, someone who wanted to clean himself, and feared Allah. However it was ignored. So verses 5-10 are also a form of reprimand by Allah to the Prophet Muhammad SAW. In the fifth verse the word "istaghna" refers to the Qurasyan people who "feel sufficient". It is not enough for wealth, but the point is that they do not need guidance. And at that time, the prophet himself was focused on serving them (the quraish). What the Prophet Muhammad SAW did could give the impression that he was more concerned with the rich than the poor, people who were respected in society than people who were not respected. So that Allah SWT intends to erase such an impression by bringing down these verses. For this reason, the above verses admonish the greatness of the Prophet Muhammad, and that the Prophet Muhammad is also human, but not like an ordinary human. Prophet Muhammad SAW is the glorious creature of Allah SWT.

Thahir bin 'Asyur emphasized that Allah's rebuke is a form of "ta'limiyah", namely education for the Prophet Muhammad [20]. When faced with two different situations. Where in this verse, the Prophet Muhammad SAW is faced with infidels to be preached, and to Muslims who want to be closer to Islam. As for people who feel they don't need it, then you 
serve them even though there is nothing (reproach) for you if they don't clean themselves. And whoever comes to you immediately is afraid, then you ignore him. " Surah 'Abasa verses 5-10 contain "mu'amalah" sharia education which is carried out on fellow human beings, by teaching them to be careful and careful in taking an action.

\subsection{Patterns of Teacher Interaction with Students Contained in the Al-Qur'an}

Based on the interpretation of the surah 'Abasa Verses 1-10, it can be said that there is a three-way interaction pattern, because of the action from the teacher to the student, from the student to the teacher so that a teacher gets feedback from students, and between students learning from each other between students. This interaction pattern illustrates the existence of a scaffolding process (guidance) from teachers to students with the aim of correcting mistakes made by students. Teachers as givers and recipients of action, as well as students as givers and recipients of action to achieve educational goals. So that those who get education in the teaching and learning process are not only students who get lessons from a teacher, but teachers can also get lessons from students.

In detail, Abasa verses 1-10 are classified into 2 (two) interaction patterns called (1) oneto-one scaffolding and (2) peer-scaffolding. Interaction in one-to-one scaffolding, namely that Allah SWT as a teacher who teaches or provides guidance (scaffolding) by admonishing the Prophet Muhammad SAW who can be illustrated as a student. Likewise with Ibn Ummi Maktum can be illustrated as a student. So it can be described that in the surah 'Abasa verses 1-10: Prophet Muhammad SAW learns from each other with Ibn Ummi Maktum who is illustrated as a fellow student. This pattern of interaction is referred to as peer-scaffolding which refers to the provision of scaffolding support by fellow students [10], and it takes advantage of the strength of the Prophet Muhammad SAW as an educator for the messenger of Allah SWT [17] as peers who are considered smarter or more capable than other students. This peer-scaffolding type of interaction pattern each student plays a role in the teaching and learning process. The teacher will supervise and direct and guide students in the learning process. Thus, teaching and learning interactions take place reciprocally. Students (Prophet Muhammad SAW and Ibn Ummi Maktum) can receive lessons from the teacher (Allah SWT) and gain experience from other students. Activities like this lead to an interactive presence between teachers and students, as well as between students and students.

Judging from the nature of an educator (teacher) from the side of the Prophet Muhammad who received a warning from Allah SWT, a lesson was obtained that the basic nature of educators (teachers) includes: (1) Teaching that one is not allowed to differentiate between one another ( surah 'Abasa, verses 1-2); (2) teach not to think negatively towards others (surah 'Abasa, verses 3-4); and (3) Teaching to be patient [18], careful and careful in taking an action (surah 'Abasa, verses 5-10). Meanwhile, a student must have the following attitudes: obedient, steadfast, patient, have a strong will, not give up, earnestly seek knowledge, politeness, humility, and respect for the teacher.

\section{Conclusion}

After studying and analyzing the interaction patterns of the teacher with students and students and students in the interpretation of the surah 'Abasa verses 1-10, the writer can draw a conclusion, namely the pattern of interaction between the teacher and students in the surah 'Abasa verses 1-10 using the one-to-one scaffolding and peer-scaffolding. Allah SWT acts as a 
teacher who gives action. Meanwhile, the Prophet Muhammad and Ibn Ummi Maktum were students. The results of the study on the pattern of teacher-student interaction in the learning scaffolding process in the review of the Al-Qur'an surah 'Abasa verses 1 - 10, namely the interactive presence between the teacher (Allah SWT) and the student (Prophet Muhammad SAW) is called one-to-one scaffolding, and the interaction between students (Prophet Muhammad SAW) and students (Ibn Ummi Maktum) is called peer-scaffolding.

The application of learning based on the internalization of Islamic values can increase the religious attitude and faith of teachers and students towards Allah SWT [19]. Scaffolding is very supportive of current performance but also aims at the target student's ability to perform learning skills independently in the future. The wisdom that can be taken from the surah 'Abasa verses $1-10$ is that we are taught not to turn away to people in need. Do not underestimate the person even though he has flaws. Giving priority to helping Muslims in need is more important than preaching Islam to arrogant kafirs. Because increasing the faith of a Muslim can strengthen unity. Meanwhile, preaching the ignorant disbelievers is only meaningless and does not bring good to them.

\section{References}

[1] Rinaldi I, Zein A. Nilai-Nilai Pendidikan Dalam Alquran ( Kajian Kisah Nabi Daud As ). Edu Relig. 2018;2(2):197-207.

[2] Susilawati. Nilai-Nilai Pendidikan Melalui Kisah Dalam Al-Qur'an. Belajea J Pendidik Islam. 2016;1(1):23-40.

[3] Shabani K. Applications of Vygotsky's sociocultural approach for teachers' professional development. Cogent Educ [Internet]. 2016;3(1). Available from: http://dx.doi.org/10.1080/2331186X.2016.1252177

[4] Hammond D, Flook L, Harvey LC, Barron C, Osher B, Osher D. Implications for educational practice of the science of learning and development. Appl Dev Sci [Internet]. 2019;0(0):1-44. Available from: https://doi.org/10.1080/10888691.2018.1537791

[5] Ajmain, Marzuki. The role of teachers and headmaster in character education of student of SMA 3 Yogyakarta. SOCIA J Ilmu-Ilmu Sos. 2019;16(1):109-23.

[6] Kusmaryono I, Gufron AM, Rusdiantoro A. Effectiveness of Scaffolding Strategies in Learning Against Decrease in Mathematics Anxiety Level. Numer J Mat dan Pendidik Mat. 2020;4(1):13-22.

[7] Lu J, Lajoie SP, Wiseman J. Scaffolding problem-based learning with CSCL tools. Int J Comput Collab Learn. 2010;5(3):283-98.

[8] Bakker A, Smit J, Wegerif R. Scaffolding and dialogic teaching in mathematics education: introduction and review. ZDM - Math Educ. 2015;47(7):1047-65.

[9] Huang K. Design and investigation of cooperative, scaffolded wiki learning activities in an online graduate-level course. Int J Educ Technol High Educ. 2019;16(1).

[10] Kim NJ, Belland BR, Walker AE. Effectiveness of Computer-Based Scaffolding in the Context of Problem-Based Learning for Stem Education: Bayesian Meta-analysis. Educ Psychol Rev. 2018;30(2):397-429.

[11] Prediger S, Pöhler B. The interplay of micro- and macro-scaffolding: an empirical reconstruction for the case of an intervention on percentages. ZDM Math Educ. 2015;47(7):1179-94.

[12] Retnidari W, Elbas WF, Loviana S. Scaffolding dalam Pembelajaran Matematika. 
Linear J Math Educ. 2020;1(1):15-21.

[13] van de Pol J, Mercer N, Volman M. Scaffolding Student Understanding in SmallGroup Work: Students' Uptake of Teacher Support in Subsequent Small-Group Interaction. J Learn Sci. 2019;28(2):206-39.

[14] Belland BR, Evidence E. Instructional Scaffolding in STEM Education. Switzerland: Springer International Publishing AG Switzerland; 2016. 150 p.

[15] Khalaf BK, Zin ZBM. Traditional and inquiry-based learning pedagogy: A systematic critical review. Int J Instr. 2018;11(4):545-64.

[16] Martins LEG, Gorschek T. Requirements engineering for safety-critical systems: A systematic literature review. Inf Softw Technol. 2016;75:71-89.

[17] Noviza et al. "The dynamic of Malay Islamic Word in Responding to Contempores Global Issue“. In: Proceeding International Seminar [Internet]. 2016. p. 1-2. Available from: https://core.ac.uk/download/pdf/291986913.pdf

[18] Hai KA. The Islamic Education Methods in Al-Quran. Ta'dib. 2017;22(1):48-57.

[19] Waluyo S. Nilai Nilai Pendidikan Akhlak Dalam Al Quran. Al Riwayah J Pendidik. 2018;10(September):269-95.

[20] Ulia N, Sari Y, Hariyono M. Pengaruh Bahan Ajar Konsep Dasar Matematika Berbasis Internalisasi Nilai-Nilai Islam Terhadap Sikap Religius. J Stud Guru dan Pembelajaran. 2020;3(1):1-10. 